\title{
Evaluation of Growth Performance and Survival Rate of African Catfish (Clarias gariepinus) Fed with Graded Levels of Egg Shell Substituted Ration
}

\author{
OA Bello-Olusoji ${ }^{1}$, MO Sodamola ${ }^{2 *}$, YA Adejola ${ }^{2}$ and DD Akinbola ${ }^{2}$ \\ ${ }^{1}$ Department of Fisheries and Wildlife, Federal University of Technology, Akure, Nigeria \\ ${ }^{2}$ Federal College of Agriculture, Moor Plantation, Apata, Ibadan, Nigeria \\ *Corresponding Author: MO Sodamola, Federal College of Agriculture, Moor Plantation, Apata, Ibadan, Nigeria.
}

Received: June 07, 2017; Published: July 24, 2019

DOI: $10.31080 /$ ASNH.2019.03.0375

\begin{abstract}
An eight (8) weeks study was carried out on Four hundred and five (405) African catfish (Clarias gariepinus) juveniles to examine the effect of graded levels of egg shell on their growth performance and survival rates. They were acclimatized for two (2) weeks after which they were weighed and allotted into five dietary treatments of three (3) replicates each and 27 fishes per replicate making a total number of eighty-one (81) fishes per treatment. The dietary treatments contained 0, 25, 50, 75 and 100(\%) egg shell inclusion from treatment one to treatment five respectively. Parameter on daily feed intake, weekly weight gain and daily mortalities were recorded. The result of the experiment indicated that treatment four (4) with 75\% inclusion of egg shell was the best in terms of weight gain and survival rates and was significantly different $(\mathrm{P}<0.05)$ when compared with the other treatments. For Catfish farming to remain viable in the nearest future, lower feed cost and increased profit are required; it is therefore recommended that diets of African catfish (Clarias gariepinus) be supplemented with well processed egg shell at $75 \%$ level of inclusion to achieve this.
\end{abstract}

Keywords: African Catfish; Egg Shell; Performance; Performance; Survival Rate; Weight Gain

\section{Introduction}

African Catfish, Clarias gariepinus is undoubtedly ideal aquaculture specie in the world and is widely distributed [1]. It is hardy, adaptable with ability to withstand adverse environmental conditions [2]. It is mostly bred due to its wide range of distribution, tolerance to variable temperature, high feed conversion and accessory breathing organs which enable them to survive for sometimes out of water [3].

Fish needs feeds to grow, irrespective of the good health, quality or condition of their environment and if this is not adequately supplied, a malnourish condition may occur $[4,5]$ stated that inability of aquatic animal to absorb inorganic elements from their external surrounding is one of the major problems among many factors in deciding the mineral requirements quantitatively. There is a general problem encountered in mineral nutrition research such as formulating minerals-free-diet and overcoming tissues stores of minerals. Feed management determines the viability of aquaculture as its accounts for at least 60 percent of the cost of fish production. Fish require a dietary source of calcium and phosphorus to meet their relatively high metabolic requirements.

According to [6] Calcium and Phosphorus make up 70\% of the total mineral elements in the body and are essential for the formation of bone, energy transfer through adenosine triphosphate
(ATP) and an essential component of buffer systems in the blood [7]. Noted that Phosphorus is involved in the control of appetite, weight and feed efficiency while [8] asserted that inadequate supply of Phosphorus may lead to severe consequences in terms of reduced performance, excessive mortality, and reduction in carcass quality.

There are various sources of calcium and phosphorus among which are bone meal, egg shell, di-calcium phosphate (DCP) and oyster shell. These sources have different proportion of calcium and phosphorus; some are rich in calcium while others are rich in phosphorus.

Efficient utilization of by-products of poultry has direct impact on the economy and environmental pollution of the country by reducing the loss of potential revenues as well as the cost of disposal of these products [9]. Waste products from the poultry processing especially the egg producing industries could be efficiently utilized and converted into useful products of higher value [10]. Egg shell is one of such by-products from the egg producing industries which contains calcite, a crystalline form of calcium carbonate that serve as bone building materials [11]. It was reported that $94 \%$ of a dry shell is calcium carbonate with a typical mass of $5.5 \mathrm{~g}$ while the remaining mass is composed largely of phosphorus and magnesium and some trace amount of sodium, potassium, zinc, manganese, iron and copper (Gary., et al. 2004). Based on the findings of [12] 
Evaluation of Growth Performance and Survival Rate of African Catfish (Clarias gariepinus) Fed with Graded Levels of Egg Shell Substituted Ration

egg shells are useful by-product that can be used as supplements to supply calcium to a reasonable level in the diet of African Catfish (C. gariepinus). It therefore becomes imperative to reduce the expenses on Catfish farming by employing the use of well processed egg shell as substitute for other expensive feed ingredients in their diets. The aim of the study is to determine the effect of graded level of egg shell on the growth performance, carcass characteristics and survival rate of African catfish juveniles.

\section{Materials and Methods}

Experimental Site

The experiment was carried out at the fishery unit of the teaching and research farm of Federal College of Agriculture, Moor plantation, Ibadan.

Experimental Design

Four hundred and five (405) African Catfish juveniles of weight ranging from 72 - 76g were purchased from Aquatech Nigeria limited, Ibadan. They were acclimatized for two (2) weeks after which they were weighed and allotted into five dietary treatments of three (3) replicates each and 27 fishes per replicate.

Experimental diets comprise 0, 25, 50, 75 and 100(\%) graded levels of egg shell mixed with compounded feed from treatment 1 (T1) to treatment 5 (T5) respectively.

$\mathrm{T} 1=$ compounded feed $+0 \%$ inclusion of egg shell (control)

$\mathrm{T} 2=$ compounded feed $+25 \%$ inclusion of egg shell

$\mathrm{T} 3=$ compounded feed $+50 \%$ inclusion of egg shell

$\mathrm{T} 4=$ compounded feed $+75 \%$ inclusion of egg shell

$\mathrm{T} 5=$ compounded feed $+100 \%$ inclusion of egg shell

Egg shell used obtained from God's will hatchery, Oluyole, Ibadan was air dried for a week and grounded to powder afterwards.

\begin{tabular}{|l|c|c|c|c|c|}
\hline $\begin{array}{c}\text { Ingredients } \\
\mathbf{( \% )}\end{array}$ & $\begin{array}{c}\text { T1 } \\
\mathbf{( 0 \% )}\end{array}$ & $\begin{array}{c}\text { T2 } \\
\mathbf{( 2 5 \% )}\end{array}$ & $\begin{array}{c}\text { T3 } \\
\mathbf{( 5 0 \% )}\end{array}$ & $\begin{array}{c}\text { T4 } \\
\mathbf{( 7 5 \% )}\end{array}$ & $\begin{array}{c}\text { T5 } \\
\mathbf{( 1 0 0 \% )}\end{array}$ \\
\hline Maize & 10.00 & 10.00 & 10.00 & 10.00 & 10.00 \\
\hline $\begin{array}{l}\text { Soya bean } \\
\text { meal }\end{array}$ & 45.24 & 45.24 & 45.24 & 45.24 & 45.24 \\
\hline Fish meal & 27.78 & 27.78 & 27.78 & 27.78 & 27.78 \\
\hline Bone meal & 2.50 & 1.88 & 1.25 & 0.63 & 0.00 \\
\hline Egg shell & 0.00 & 0.63 & 1.25 & 1.88 & 2.50 \\
\hline Starch & 11.98 & 11.98 & 11.98 & 11.98 & 11.98 \\
\hline $\begin{array}{l}\text { Vitamin pre- } \\
\text { mix }\end{array}$ & 2.50 & 2.50 & 2.50 & 2.50 & 2.50 \\
\hline Total & 100.00 & 100.00 & 100.00 & 100.00 & 100.00 \\
\hline
\end{tabular}

Table I: Gross Composition of the Experimental Diets.
Experimental diets were given twice daily (in the morning and evening) using $4 \%$ of their body weight. Water replacement was done weekly to improve its quality and reduce pollution. Weight measurement per replicate were carried out on weekly basis and early in the morning to reduce stress, record on daily feed intake, weekly body weight gain and mortalities were also taken.

\begin{tabular}{|l|c|c|c|c|c|c|}
\hline $\begin{array}{c}\text { Experi- } \\
\text { mental } \\
\text { diets }\end{array}$ & $\begin{array}{c}\text { Crude } \\
\text { Protein } \\
\text { (\%) }\end{array}$ & $\begin{array}{c}\text { Crude } \\
\text { fat (\%) }\end{array}$ & $\begin{array}{c}\text { Crude } \\
\text { Fibre } \\
\text { (\%) }\end{array}$ & $\begin{array}{c}\text { Ash } \\
\text { (\%) }\end{array}$ & $\begin{array}{c}\text { Moisture } \\
\text { (\%) }\end{array}$ & $\begin{array}{c}\text { Dry } \\
\text { matter } \\
\text { (\%) }\end{array}$ \\
\hline $\begin{array}{l}\text { Treament } \\
1\end{array}$ & 41.86 & 3.18 & 2.67 & 9.76 & 8.65 & 33.88 \\
\hline $\begin{array}{l}\text { Treament } \\
2\end{array}$ & 42.45 & 3.25 & 2.49 & 10.86 & 8.54 & 32.41 \\
\hline $\begin{array}{l}\text { Treament } \\
3\end{array}$ & 41.97 & 3.29 & 2.53 & 10.69 & 8.74 & 32.78 \\
\hline Treament & 45.59 & 3.15 & 2.74 & 9.97 & 8.48 & 33.07 \\
\hline $\begin{array}{l}\text { Treament } \\
5\end{array}$ & 42.78 & 3.31 & 2.44 & 10.95 & 8.26 & 32.26 \\
\hline $\begin{array}{l}\text { Test } \\
\text { ingredent }\end{array}$ & 0.14 & 0.08 & 0.13 & 11.28 & 6.11 & 82.26 \\
\hline
\end{tabular}

Table 2: Proximate Composition of the Experimental Diets.

\begin{tabular}{|c|c|c|c|c|c|c|c|}
\hline \%Ca & $\% \mathbf{P}$ & \%Na & \%k & \%Mg & $\begin{array}{c}\text { Fe } \\
\text { (mg/kg) }\end{array}$ & $\begin{array}{c}\mathbf{M n} \\
\text { (mg/kg) }\end{array}$ & $\begin{array}{c}\text { Cu } \\
\text { (mg/kg) }\end{array}$ \\
\hline 29.38 & 0.07 & 0.17 & 0.49 & 0.24 & 22618.00 & 118.00 & 1.20 \\
\hline
\end{tabular}

Table 3: Mineral Composition of the Test Ingredient.

\section{Statistical Analysis}

Data collected was subjected to analysis of variance (ANOVA) using SAS statistical package (SAS, 1999). Means were separated using Duncan multiple range test.

\section{Results}

Table 2 showed the effect of egg shell inclusion on the growth performance and survival rates of catfish (Clarias gariepinus). Significant differences $(\mathrm{p}<0.05)$ across the different dietary treatments was recorded on final weight and total weight gain while the other parameters were not significantly different $(p>0.05)$.

Fishes in treatment 4 had the highest value of final weight $(11.67 \mathrm{~g})$ while treatment 2 recorded the lowest $(7.00 \mathrm{~g})$. The total weight gain across the dietary treatment follows the same trend as the final weight. 
Evaluation of Growth Performance and Survival Rate of African Catfish (Clarias gariepinus) Fed with Graded Levels of Egg Shell Substituted Ration

\begin{tabular}{|l|c|c|c|c|c|}
\hline \multicolumn{1}{|c|}{ Parameters } & T1 & T2 & T3 & T4 & T5 \\
\hline Initial weight(g) & 2.67 & 2.67 & 2.67 & 2.67 & 2.67 \\
\hline Final weight (g) & $7.00^{\mathrm{c}}$ & $8.33^{\mathrm{b}}$ & $9.67^{\mathrm{ab}}$ & $11.67^{\mathrm{a}}$ & $8.00^{\mathrm{c}}$ \\
\hline Total weight gain(g) & $4.33^{\mathrm{c}}$ & $5.66^{\mathrm{b}}$ & $7.00^{\mathrm{ab}}$ & $9.00^{\mathrm{a}}$ & $5.33^{\mathrm{c}}$ \\
\hline Average weight gain (g) & 0.54 & 0.71 & 0.89 & 1.13 & 0.67 \\
\hline Survival rate (\%) & 52.00 & 55.00 & 68.00 & 74.00 & 50.00 \\
\hline
\end{tabular}

\section{Discussion}

The effect of $0 \%$ level of inclusion of egg shell in treatment 1 gave the least weight gain $(4.33 \mathrm{~g})$. This could be as a result of deficiency of mineral caused by dietary imbalance of calcium and phosphorus as stated by Nakamura (1982). It was observed from the study that treatment four (4) with 75\% egg shell inclusion had the best final weight of $11.67 \mathrm{~g}$. This supported the findings of [13] who reported that fish with adequate supplement apart from the main feed gain body weight faster. The result is also in line with the findings of [14] who observed better growth rate after supplementing their diet with $75 \%$ of egg shell.

\section{Conclusion}

The aim of any aquaculture business is to reduce income spent on feed, increase capital income of the owner and improve the nutritional yield of its consumer. It can be concluded from the study that egg shell at the rate of $75 \%$ should be used as supplement to replace bone meal in the diet of African Catfish (Clarias gariepi$n u s$ ) as it has been discovered to yield preferably weight gain and high survival rate.

Hence, there is a need to boost the production of this highly demanded cultured fish with low-cost balanced diet feed for aquaculture sustainability and food security in Nigeria.

\section{Bibliography}

1. FAO. "World Agriculture toward 2015/ 2030, FAO". (2006).

2. Nyina-Wamwiza L., et al. "Partial0020or total replacement of fish meal by agricultural by-products in diets of juvenile African catfish (Clarias gariepinus), growth performance, feed efficiency and digestibility". Aquaculture nutrition 16.3 (2009): 237-247.

3. Morakinyo B. "Breeds, biology and culture of Catfish". Elsevier science publishers (2006): 1-14.

4. Fagbenro OA. "A review of biological and economical principles underlying com-mercial fish culture production in Nigeria". Journal West African Fisheries 3 (1987): 171-177.

5. De Silva SS. "Feed Resources and sustainability. In: Sustainable Aquaculture - Food for the Future". (1999): 221-241.

6. Nwanna LC., et al. "Effect of graded levels of phosphorus on growth and mineral concentration in giant African catfish, Heterobranchus bi-dorsalis". African Journal of Biotechnology 8.16 (2009): 3947-3953.

7. McDowell LR. "Minerals in animal and human nutrition". 252 (1992).

8. Waldroup PW. "Nutritional approaches to reducing phosphorus excretion in poultry". Poultry Science 78.5 (1999): 683-691. Journal of Fisheries and Aquatic Science 2: 375-386. 
9. Russ W and Pittroff RM. "Utilizing waste products from the production and processing industries". Critical Reviews in Food Science and Nutrition 44(2) (2004): 57-62.

10. Jayathilakan k., et al. "Utilization of by products and waste materials from meat, poultry and fish processing industries; a review". Journal of food Science Technology 49.3 (2012): 278293.

11. Gary A and Arnandez. "Poultry products and their uses". (2000): 72-74.

12. Jill W. "Thirty things to do with egg shells". Journal of Practice Homestead 136 (2012).

13. Sogbesan OA., et al. "Culture and utilization of earthworm as animal protein supplement in the diet of Heterobranchus longifilis fingerlings". (2007).

14. Brand TS., et al. "The effect of different dietary vitamin and mineral levels on certain production parameters, including egg shell characteristics of breeding ostriches". South African Journal of Animal Science 44.5 (2014).

\section{Volume 23 Issue 8 August 2019}

(c) All rights are reserved by MO Sodamola., et al. 